\title{
PERBANDINGAN KEMAMPUAN LITERASI MATEMATIKA SISWA ANTARA MADRASAH NEGERI DENGAN SISWA MADRASAH SWASTA
}

\author{
Rina Mariani \\ Prodi Tadris Matematika, Universitas Islam Negeri Mataram, rinamariani8@gmail.com
}

\section{INFO ARTIKEL}

Riwayat Artikel:

Diterima: 23-01-2017

Disetujui: 30-03-2017

\section{Kata Kunci:}

Kemampuan Literasi

Madrasah Negeri

Madrasah Swasta

\section{A. LATAR BELAKANG}

Belajar di madrasah negeri atau swasta mempunyai sensasi yang berbeda bagi para peserta didik. Perbedaan madrasah negeri dan madrasah swasta menjadi pembicaraan publik, tidak jarang masyarakat yang tidak tahu menahu akhirnya mengambil kesimpulan sepihak yang mengatakan bahwa madrasah negeri lebih baik dari madrasah swasta.

Proses pembelajaran antara madrasah negeri dan swasta tentu memiliki perbedaan. Karena input dari masing-masing madrasah tersebut berbeda. Madrasah negeri cendrung memiliki input yang berkualitas, karena peserta didik yang berkemampuan baik yaitu lulusan terbaik dari madrasah sebelumnya lebih memilih madrasah negeri sebagai pilihan pertama untuk melanjutkan pendidikan mereka. Sedangkan peserta didik yang tidak diterima di madrasah negeri yaitu peserta didik yang tidak bisa bersaing dengan peserta didik yang kemampuannya lebih baik untuk masuk madrasah negeri memilih madrasah swasta sebagai pilihan terakhir. Tidak hanya itu, dari kualitas pengajar/guru madrasah negeri tentu lebih baik, karena guru yang mengajar di madrasah negeri adalah guru yang ahli sesuai dengan bidangnya. Berbeda dengan madrasah swasta yang kekurangan guru, mengakibatkan guru berperan ganda dalam memegang bidang studi pelajaran. Hal ini yang menyebabkan suasana pembelajaran di madrasah negeri akan berbeda dibandingkan dengan madrasah swasta, sehingga proses pembelajaran di madrasah negeri tentu lebih mendukung dari pada madrasah swasta.

Literasi matematika adalah kemampuan seseorang untuk merumuskan, menerapkan dan menafsirkan matematika dalam berbagai konteks, termasuk kemampuan melakukan penalaran secara matematis dan menggunakan konsep, prosedur dan fakta untuk menggambarakan, menjelaskan atau memperkirakan fenomena atau kejadian. Agar menjadi orang yang memiliki literasi matematika, siswa perlu memiliki seluruh 5 kompetensi tersebut meskipun dalam derajat/tingkat yang berbeda. Menumbuhkan literasi matematika pada siswa harus didukung oleh suasana belajar yang baik. Seseorang guru hendaknya dapat menciptakan suasana belajar yang memungkinkan bagi siswa untuk secara aktif belajar dengan mengkontruksikan, menemukan dan mengembangkan pengetahuannya.

Berdasarkan uraian di atas nampak perbedaan antara madrasah negeri dan madrasah swasta baik dari profesionalisme guru, input yang dimiliki madrasah, serta proses pembelajaran yang berlangsung di madrasah. Oleh karena itu, peneliti tertarik melakukan penelitian untuk mengetahui apakah dengan perbedaan tersebut memberikan dampak pada perbedaan kemampuan literasi matematika dalam madrasah negeri dan swasta. 


\section{B. METODE PENELITIAN}

\section{Desain Dan Metode}

Desain yang digunakan dalam penelitian ini adalah menggunakan pendekatan kuantitatif karena data yang diperoleh berupa angka-angka maka akan diproses dengan cara menghimpun, mengatur, menyusun, mengolah, menyajikan, dan menganalisa. Adapun jenis penelitian yang digunakan pada penelitian ini yakni penelitian kausal komparatif.

Metode yang digunakan dalam pengumpulan data adalah: (a) metode dokumentasi, metode ini digunakan untuk mendapatkan data terkait data MA Negeri 2 Mataram dan MA NW Mataram. (b) metode tes, tes yang digunakan dalam penelitian ini adalah tes inteligensi yang berbentuk instrument essay. Melalui tes ini Siswa Kelas XI IPS MAN 2 Mataram dan MA NW Mataram diberikan sederetan pertanyaan mengenai pengetahuan matematika (literasi matematika) sebagai subjek penelitian.

\section{Populasi dan sample}

"Populasi adalah wilayah generalisasi yang terdiri atas objek/subjek yang mempunyai kualitas dan karakteristik tertentu yang ditetapkan oleh peneliti untuk dipelajari dan kemudian ditarik kesimpulannya."[1] Populasi dalam penelitian ini adalah MA Negeri Dan MA Swasta yang ada di Kota Mataram seperti pada Tabel 1.

TABEL 1

DAFTAR MA NEGERI DAN SWASTA DI MATARAM

\begin{tabular}{|c|c|}
\hline MADRASAH NEGERI & MADRASAH SWASTA \\
\hline MAN 2 Mataram & MA NW Mataram \\
\hline MAN 1 Mataram & MA AL-Barokah \\
\hline & MA Darul Falah \\
\hline & MA AL-intishor \\
\hline & MA Ar-rasyiah \\
\hline & MA AL-Madaniyah \\
\hline
\end{tabular}

Menurut nurul zuriah, sampel adalah bagian dari populasi.[2] Sampel ini dilakukan jika jumlah populasinya terlalu besar dan untuk menghemat dana, waktu dan tenaga. Sampel dalam penelitian ini adalah MAN 2 Mataram dan MA NW Mataram dengan menggunakan tekhnik purposive sampling.

\section{Instrumen Penelitian}

Instrumen penelitian atau disebut juga dengan alat ukur dalam penelitian. Menurut Sugiyono " instrumen penelitian adalah suatu alat yang digunakan mengukur fenomena alam maupun social yang diamati.".[3]

Instrument pada penelitian ini adalah soal tes. Dalam penyusunan soal ini, peneliti hanya mengambil 2 komponen dari 5 komponenen yang ada dalam kemampuan literasi matematika yaitu komponen penalaran matematis dan representasi matematis. Hasil skor tes Kemampuan literasi matematika siswa yang diperoleh peneliti diinterpretasikan pada Tabel 2 .

TABEL 2

INTERPRETASIKAN KEMAMPUAN LITERASI MATEMATIKA SISWA BERDASARKAN SKOR TES

\begin{tabular}{|c|c|}
\hline Skor yang diperoleh & Kategori \\
\hline Skor $76-100$ & Tinggi \\
\hline Skor $51-75$ & Sedang \\
\hline Skor $26-50$ & Kurang \\
\hline Skor $0-25$ & Sangat Kurang \\
\hline
\end{tabular}

\section{Teknik Pengumpulan Data}

Dalam penelitian, teknik pengumpulan data yang peneliti gunakan dintaranya adalah:

a. Metode dokumentasi

Dokumentasi merupakan suatu metode yang digunakan untuk mencari data mengenai hal-hal yang berupa catatan, transkrip, buku, surat kabar, majalah, prasasti, notulen rapat, leger, agenda, dan sebagainya.

b. Metode Tes

Tes adalah serentetan pertanyaan atau latihan serta alat lain yang digunakan untuk mengukur keterampilan, pengetahuan inteligensi, kemampuan atau bakat yang dimiliki oleh individu atau kelompok. [4]

Tes yang digunakan dalam penelitian ini adalah tes inteligensi yang berbentuk instrument essay. Tes ini diberikan pada siswa dengan tujuan untuk memperoleh data yang di inginkan oleh peneliti yaitu untuk mengukur suatu variabel yang diteliti. [5] Melalui tes ini diberikan sederetan pertanyaan mengenai pengetahuan matematika (literasi matematika) Siswa Kelas XI IPS MAN 2 Mataram dan MA NW Mataram sebagai subjek penelitian ini.

\section{Teknik Analisis Data}

Analisis data pada penelitian ini menggunakan analisis uji t yaitu:

$$
\mathrm{t}=\frac{X_{1}-X_{2}}{\sqrt{\frac{s_{1}^{2}}{n_{1}}+\frac{s_{2}^{2}}{n_{2}}-2 r\left(\frac{s_{1}}{\sqrt{n_{1}}}\right)\left(\frac{s_{2}}{\sqrt{n_{2}}}\right)}}
$$

Penarikan kesimpulan dalam penelitian ini dengan memperhatikan rumusan hipotesis penelitian sebagai berikut:

a. $\mathrm{H}_{0}$ : Kemampuan matematika antara siswa madrasah negeri sama dengan siswa madrasah swasta.

b. $\mathrm{H}_{1}$ : Kemampuan matematika antara siswa madrasah negeri tidak sama dengan siswa madrasah swasta. 
Jika $-t_{\text {tabel }} \leq t_{\text {hitung }} \leq t$, Ho $_{0}$ di terima jika nilai berada dalam interval dan ditolak jika nilai berada di luar interval.

\section{HASIL DAN PEMBAHASAN}

\section{Pengumpulan dan Penyajian Data}

Pengukuran kemampuan literasi matematika siswa MAN 2 Mataram dan MA NW Mataram, peneliti memberikan soal tes yang terdiri dari 4 item pernyataan terkait dengan kemampuan literasi matematika. Soal ini diberikan kepada seluruh siswa kelas XI IPS 2 MAN 2 Mataram sebanyak 37 siswa dan XI IPS MA NW Mataram Kediri sebanyak 14 siswa. Pemberian soal tes ini dilaksanakan masing-masing selama 1 hari yaitu di MAN 2 Mataram pada hari senin tanggal 29 oktober 2014 dan di MA NW Mataram pada hari kamis tanggal 2 september 2014. Rangkuman statistik dari data hasil penelitian yang diperoleh dapat dilihat pada Tabel 3.

TABEL 3

RANGKUMAN STATISTIK

\begin{tabular}{|l|c|c|}
\hline \multicolumn{1}{|c|}{ Statistik } & $\begin{array}{c}\text { MAN 2 } \\
\text { Mataram }\end{array}$ & $\begin{array}{c}\text { MA Nurul Wathan } \\
\text { Mataram }\end{array}$ \\
\hline $\begin{array}{l}\text { Jumlah } \\
\text { Responden }\end{array}$ & 37 & 14 \\
\hline Rata-rata & 60,257 & 15,29 \\
\hline Varian & 189,1892 & 193,1429 \\
\hline Nilai Tertinggi & 91,5 & 40 \\
\hline Nilai Terendah & 34 & 1 \\
\hline Skor Tertinggi & 100 & 100 \\
\hline Skor Terendah & 0 & 0 \\
\hline Rentang & 57,5 & 39 \\
\hline
\end{tabular}

Tabel 3 menginformasikan bahwa Rata-rata kemampuan literasi matematika dari siswa di MAN 2 Mataram sebesar 60,257 dengan varian 189,1892. Nilai tertinggi yang diperoleh oleh siswa adalah 91,5 dan nilai terendah sebesar 34 dan rentang sebesar 57,5. Skor maksimum (tertinggi) yang bisa diperoleh oleh siswa yaitu 100 dan skor minimum (terendah) adalah 0 . Sedangkan untuk MA NW Mataram, rata-rata kemampuan literasi matematika dari siswa sebesar 15,29 dengan varian 193,1429. Nilai tertinggi yang diperoleh oleh siswa adalah 40 dan nilai terendah sebesar 1 dan rentang sebesar 39. skor maksimum (tertinggi) yang bisa diperoleh oleh siswa yaitu 100 dan skor minimum (terendah) adalah 0. Data hasil penelitian juga dapat dilihat dalam bentuk diagram pada Gambar 1 dan 2.

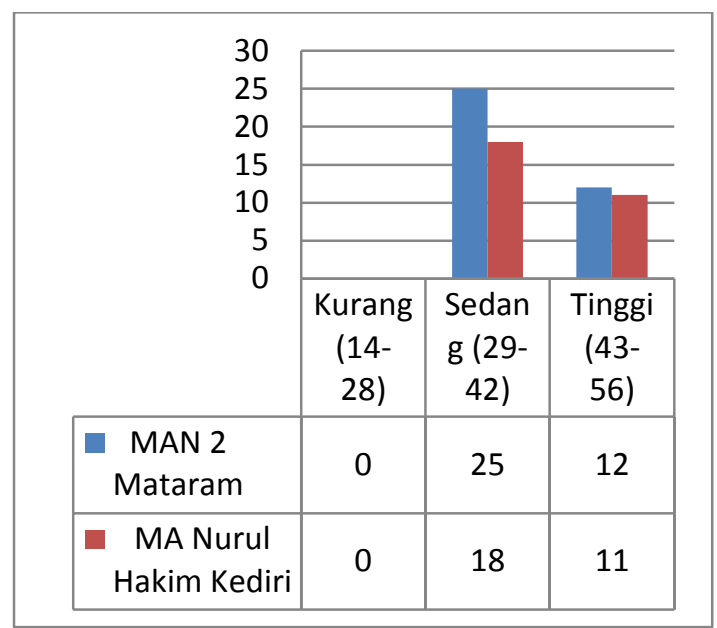

Gambar 1. Diagram batang kemampuan literasi matematika siswa MAN 2 Mataram dan MA Nurul Hakim Kediri.

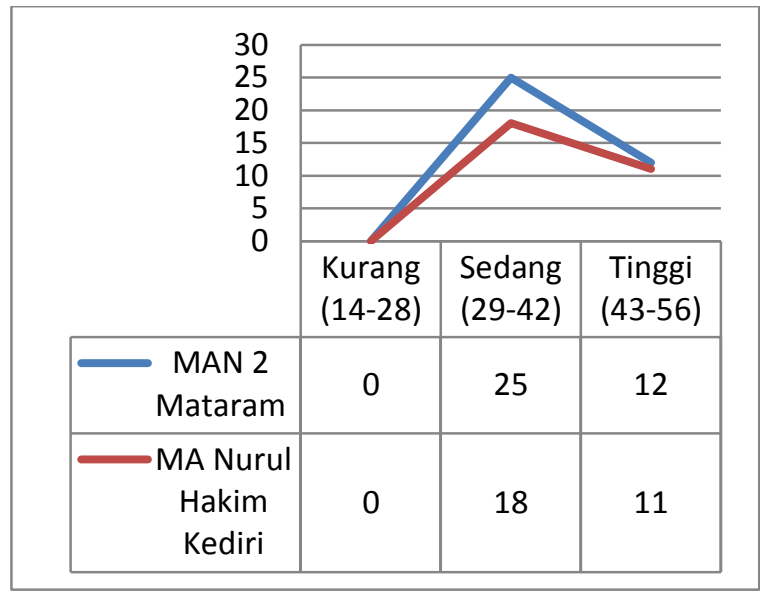

Gambar 2. Data poligon kemampuan literasi matematika siswa MAN 2 Mataram dan MA Nurul Hakim Kediri.

\section{Hasil Analisis Data}

Hasil Uji hipotesis dalam penelitian ini adalah nilai $\mathrm{t}$ hitung sebesar 10,391. Sedangkan $\mathrm{t}$ tabel yang diperoleh dengan $\propto=5 \%: 2=2,5 \%$ (uji 2 sisi) dan drajat kebebasan (df) n-2 yaitu 51-2 = 49 adalah 2,01155. Hal ini berarti $\mathrm{t}$ hitung $>$ dari $\mathrm{t}$ tabel yaitu $10391>2$, 01155 Sehingga diputuskan bahwa $\mathrm{H}_{0}$ di tolak. Dengan demikian disimpulkan bahwa kemampuan literasi matematika siswa madrasah negeri dengan madrasah swasta berbeda.

\section{Pembahasan}

Hasil dari penelitian ini adalah kemampuan literasi matematika siswa madrasah negeri lebih unggul dari pada madrasah swasta, baik itu dari segi kemampuan penalaran matematis maupun representasi matematis siswa. Hal ini dapat dilihat dari diagram batang kemampuan literasi matematika siswa pada gambar 1 dan 2, dimana pada kategori tinggi siswa madrasah negeri memiliki kemampuan literasi matematika berjumlah 5 orang, sedangkan siswa madrasah swasta tidak ada satu orang pun kemampuan literasi matematikanya berada di kategori tinggi. Begitu juga pada kategori sedang, siswa madrasah negeri memiliki kemampuan literasi matematika berjumlah 23 orang, 
12 Paedagoria | Vol. 8, No. 1, April 2017, hal 9-12

sedangkan siswa madrasah swasta tidak ada 1 orang pun kemampuan literasi matematikanya berada di kategori sedang. Pada kategori kurang, jumlah siswa madrasah swasta yang berada pada kategori tersebut adalah 9 orang dan siswa madrasah swasta berjumlah 3 orang. Dan yang terakhir pada kategori sangat kurang, siswa madrasah swasta lebih banyak berada pada kategori ini yaitu 11 orang sedangkan untuk siswa madrasah negeri, kemampuan siswa tidak berada pada kategori ini.

\section{SIMPULAN DAN SARAN}

Berdasarkan hasil analisis data dan pembahasan dalam penelitian ini, dapat disimpulkan bahwa kemampuan literasi matematika siswa madrasah negeri dengan siswa madrasah swasta adalah berbeda, dimana kemampuan literasi matematika siswa madrasah negeri lebih unggul dibandingkan dengan madrasah swasta, baik itu dari segi kemampuan penalaran matematis maupun representasi matematis .

\section{DAFTAR RUJUKAN}

1. Sugiyono, Statistika Untuk Penelitian, Alfabeta, Bandung, 2012

2. Nurul Zuriah, Metodologi Penelitian Sosial dan Pendidikan Teori-Aplikasi, PT Bumi Aksara, Jakarta, 2009

3. Sugiyono,Metode Penelitian Kuantitatif Kualitatif dan R\&D, Alfabeta, Bandung , 2011

4. Margono. Metodologi Penelitian Pendidikan, PT. Rineka Cipta, Jakarta, 2003

5. Suharsimi Prosedur Penelitian, Rineka Cipta. Jakarta, 2002 